\title{
Experience with Cortical Tunnel Fixation In Endoscopic Brow Lift - Carrier Loop Modification
}

\author{
Endoskopik Kaş Kaldırma Ameliyatındaki Tecrübelerimiz \\ - Taşıyıcı İlmek Modifikasyonu
}

Asli Datli ${ }^{1}$, Mehmet Cem Yildirim¹, Karaca Basaran²

${ }^{1} /$ stinye University, GOP Medicalpark Hospital, Plastic Surgery Clinic, Istanbul, Turkey

${ }^{2}$ Private Practice, Istanbul, Turkey

\begin{abstract}
$\ddot{O z}$
Endoskopik kaş kaldırma ameliyatının geleneksel yöntemlere kıyasla ameliyat sahasının daha iyi görülmesi, daha kısa yara izleri, alopesi riskinin ve kafa derisi duyusal değişikliklerinin daha az olması gibi birçok avantajı vardır. Kaş kaldırma ameliyatlarında doğru diseksiyon tekniği, yumuşak doku bağlantılarının etkili bir şekilde gevşetilmesi ve alın flebinin etkin bir şekilde sabitlenmesi ameliyat sonucunda önemli rol oynar. Bu yazıda, fiksasyon amacı ile kortikal kemikte açılan dar tünelden, kalın, ağırık taşıyan sütürlerin taşıyıcı ilmek ile kolayca geçirilmesine olanak sağlayan kortikal fiksasyon tekniğinin bir modifikasyonunu tanımlıyoruz.
\end{abstract}

Anahtar Kelimeler: Endoskopik kaş kaldırma, kortikal fiksasyon, taşıyıcı ilmek

\section{Abstract}

The endoscopic approach for brow lifting has many advantages such as better exposure of the operative field, shorter scars, reduced risk of alopecia and scalp sensory changes. Correct dissection technique, release of the soft tissue attachments and efficient fixation of the forehead flap play an important role in the outcome of the procedure. In this paper, we describe a modification of cortical tunnel fixation technique, which allows delivering thick, weight-bearing sutures easily from the tight cortical tunnel.

Key words: Endoscopic brow lift, cortical tunnel fixation, carrier technique
Cite this article as: Datli A, Yildirim MC, Basaran K. Experience With Cortical Tunnel Fixation In Endoscopic Brow Lift - Carrier Loop Modification. Selcuk Med J 2021;37(4): 375-377
Disclosure: None of the authors has a financial interest in any of the products, devices, or drugs mentioned in this article. The research was not sponsored by an outside organization. All authors have agreed to allow full access to the primary data and to allow the journal to review the data if requested. 


\section{INTRODUCTION}

The endoscopic technique is still one of the most commonly performed brow lift methods in forehead rejuvenation. It has certain advantages as better exposure, shorter scars, reduced risk of alopecia and scalp sensory changes compared to traditional methods (1). Although proper dissecton and release plays an important role in outcome, efficent fixation can not be underestimated. In literature, various fixation methods have been described including Endotine device (Coapt Systems, Inc, Palo Alto, CA), Mitek anchor sutures (Mitek Surgical Products, Westwood, Mass.), screws, plates, etc $(1,2)$. However, many surgeons still prefer the cortical tunnel fixation technique due to its low cost and reproducibility (3) although proper tunneling may be cumbersome (1). In this paper, we report our modification to deliver thick, weight bearing sutures from cortical tunnel with the help of conductive sutures to pave the way and save time.

\section{Operative Technique}

Two $1.5 \mathrm{~mm}$ long paramedian incisions are made corresponding with the highest desired point of the eye brow, approximately $2 \mathrm{~cm}$ posterior to the hairline. After subperiosteal dissection, two initially

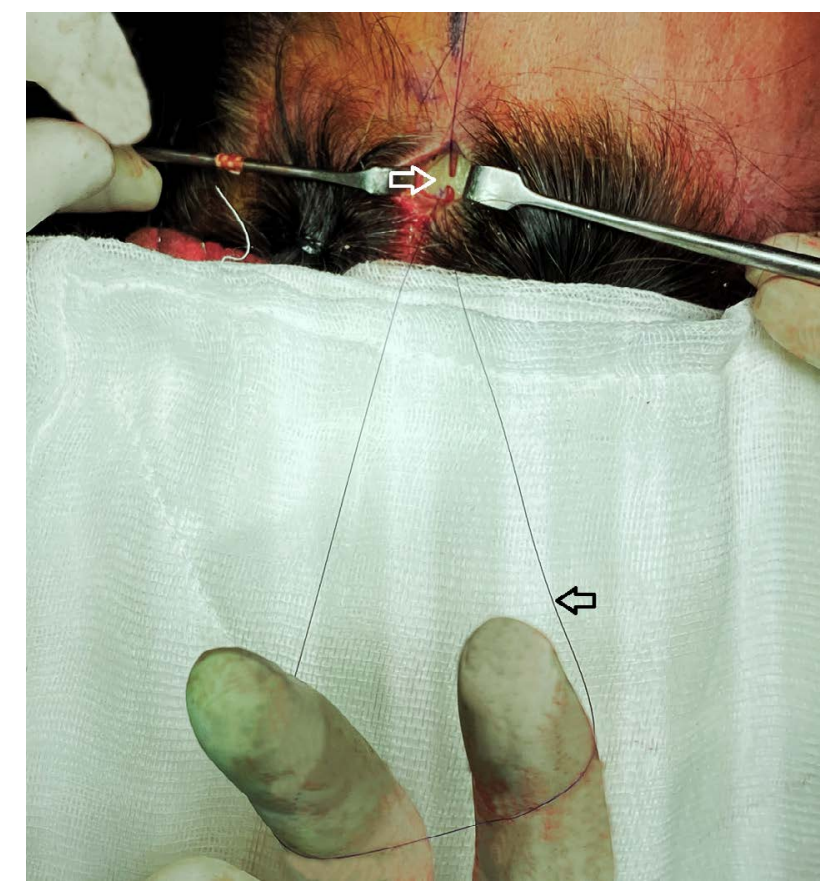

Figure 1. 5/0 round, double armed, $13 \mathrm{~mm}$ needled polypropylene suture is passed through the tunnel as a carrier by leaving a loop on the cranial side. White arrow; cortical tunnel, black arrow; the carrier loop.

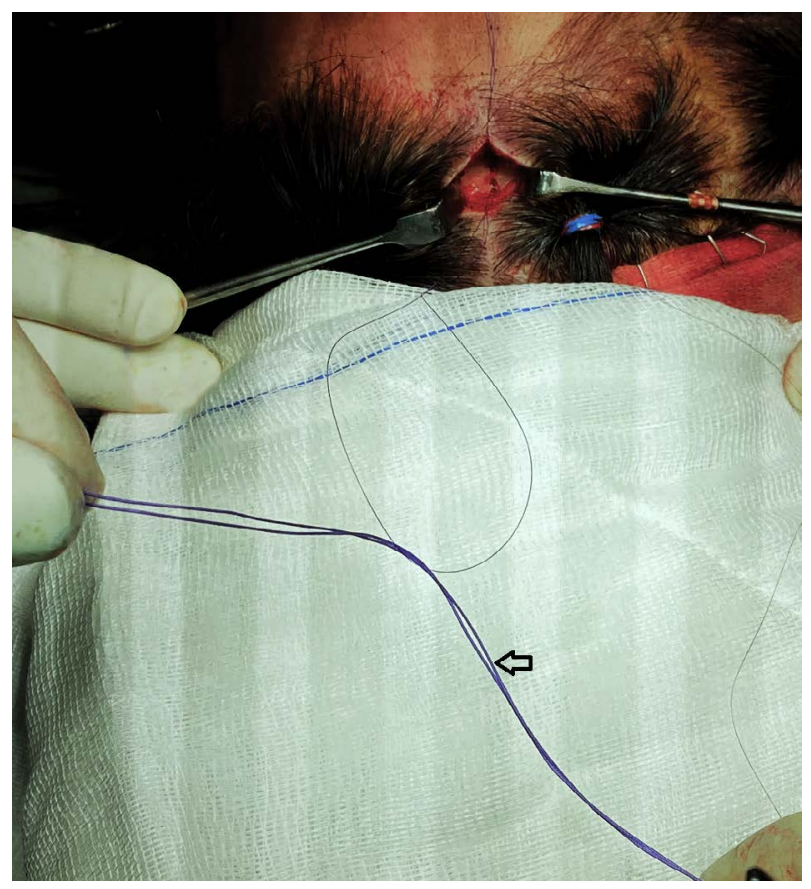

Figure 2. Black arrow; $2 / 0$ polyglactin sutures that are introduced to the carrier loop.

perpendicular holes with $2 \mathrm{~mm}$ depth and $4 \mathrm{~mm}$ intervals are placed either vertically or horizontally on each side of the head. Later, the drill is angled approximately 60 degrees to enable the suture to pass. The connection is verified with the help of a syringe by pouring saline through the holes. Since it is difficult to pass thick needled sutures $2 / 0$ polyglactin, $2 / 0$ polyester etc., (2/0 VICRYL polyglactin $40 \mathrm{~mm}$ round sutures (Ethicon, Somerville, NJ) in this case), a $5 / 0$ round, double armed, $13 \mathrm{~mm}$ needled polypropylene suture is delivered through the tunnel as a carrier by leaving a loop on the cranial side (figure 1). Then the loop is loaded with 2/0 Vicryl (figure 2). Depending on surgeon's choice, two strands of $2 / 0$ polyglactin sutures are passed through the tunnel by pulling the loop. With this manoeuver, we deliver the thick polyester sutures easily with the help of the carrier loop (video). Finally, sutures are passed from the forehead flap and fixation is achieved by anchoring in cortical bone tunnel.

In endoscopic brow lift, cortical fixation is one of the most essential steps in the positioning of the eyebrows. Among fixation methods, cortical tunnel fixation is still one of the most simple and cost-effective method. 
Video. Delivering the thick polyglactin sutures easily from narrow cortical tunnel with the help of the carrier loop.

With the 'carrier loop modification' we described a method, that overcomes the most challenging step of the cortical fixation which is passing weight bearing, thick sutures from the cortical tunnel.

Conflict of interest: Authors declare that there is no conflict of interest between the authors of the article.

Financial conflict of interest: Authors declare that they did not receive any financial support in this study.
Address correspondence to: Asli Datli, Istinye University, GOP Medicalpark Hospital, Plastic Surgery Clinic, Istanbul, Turkey.

e-mail: aslidatli@gmail.com

\section{REFERENCES}

1. Day C, Nahai F. Forehead correction of aging. In: Mathes SJ, ed. Plastic Surgery. 2nd ed. Philedelphia: Elsevier 2006: 4777.

2. Malata CM, Abood A. Experience with cortical tunnel fixation in endoscopic brow lift: The "bevel and slide" modification. Int J Surg 2009;7(6):510-5.

3. Bernardini FP, Gennai A, Izzo L, et al. Minimal incisions vertical endoscopic lifting and fat grafting as a systematic approach to the rejuvenation of the periocular esthetic unit. Ophthalmic Plast Reconstr Surg 2013;29(4):308-15. 